\title{
Dekontruksi Perempuan Abjek dalam Tiga Cerpen karangan Intan Paramaditha
}

\author{
Nungki Heriyati ${ }^{1}$ \\ ${ }^{1}$ Universitas Komputer Indonedia \\ e-mail: nungki.heriyati@email.unikom.ac.id

\begin{tabular}{ccc}
\hline Diterima & Direvisi & Disetujui \\
$10-08-2020$ & $24-08-2020$ & $31-08-2020$ \\
\hline
\end{tabular}

\begin{abstract}
This article attempts to reveal the deconstruction of abject figure in Intan Paramaditha's three short stories. The three short stories highlight a woman who is considered abject. They are described as scary monsters and must be banished because they are not part of the clean self. This study uses a descriptive analysis method that seeks to reveal the problems of abject women in a detailed and comprehensive manner. Using the abject theory initiated by Kristeva (1982), this research reveals that women who are represented as disgusting, frightening, and terrorizing monsters are patriarchal constructs. They are silenced and unable to voice themselves. The deconstruction presented by the text is able to obscure the dichotomy of good women and bitches so as to eradicate the negative construction of a patriarchal system that is attached to an abject figure and celebrates the return of the maternal body.
\end{abstract}

Key Words: Abject, Doconstruction, Monster, and Women..

\begin{abstract}
Abstrak - Artikel ini bermaksud untuk mengungkapkan dekonstruksi sosok abjek yang diangkat dalam tiga cerita pendek karya Intan Paramaditha. Ketiga cerita pendek tersebut mengetengahkan sosok perempuan yang dijadikan abjek. Mereka digambarkan seperti monster yang menakutkan dan harus disingkirkan karena bukan bagian dari diri yang bersih. Penelitian ini menggunakan metode deksripsi analisis yang berupaya mengungkapkan persoalan perempuan abjek secara mendetail dan komprehensif. Dengan menggunakan teori abjek yang digagas oleh Kristeva (1982) penelitian ini mengungkapkan perempuan yang direpresentasikan sebagai monster yang menjijikan, menakutkan, dan meneror adalah konstruksi patriarki. Mereka dibungkam dan tidak mampu menyuarakan dirinya. Dekonstruksi yang di hadirkan teks mampu mengaburkan dikotomi perempuan baik-baik dan perempuan jalang sehingga membongkat konstuksi negatif dari sistem patriarki yang lekat dengan sosok abjek dan merayakan kembalinya tubuh maternal.
\end{abstract}

Kata kunci: Abjek, Dekonstruksi, Monster, dan Perempuan.

\section{PENDAHULUAN}

Perempuan dianggap sebagai kaum marginal, warga kelas dua, dan abjek (liyan). Terlebih perempuan yang tidak memenuhi nilai-nilai femininitas sistem partrarki. Femininitas merupakan sifat-sifat yang dilekatkan dengan perempuan antara lain, lemah lembut, pasif, dan keibuan. Perempuan yang tidak memenuhi standar tersebut akan di cap buruk. Bahkan dilekati oleh stigma negatif seperti binal, perempuan gatal, dan perebut suami orang.

Intan Paramaditha dalam tiga cerpennya Perempuan Buta tanpa Ibu Jari, Vampir, dan Darah berusaha membongkar suara perempuan yang dibungkam baik dalam cerita anak-anak maupun mitos. Paramaditha bukan hanya mendekonstruksi cerita anak dan mitos tersebut namun juga memformulasikan ulang sesuatu yang dianggap abjek (liyan) sekaligus mempertanyakan nilai-nilai femininitas yang diagungkan oleh sistem patriarki.

Mitos tentang perempuan baik hati dan penyabar berusaha dibongkar disini. Pembongkaran mitos dan cerita anak menyebabkan adanya intertekstualitas dalam karena mengacu pada cerita cerita dan mitos yang populer di masyarakat. Dalam cerpennya Intan sengaja menggambarkan perempuan yang menjadi hantu dan jahat atau menjadi abjek (liyan). Cerpen ini merangkul keliyan-an perempuan tapi sekaligus juga mendekonstruksi pemikiran pembaca tentang penggambaran perempuan tersebut.

Dengan adanya dekonstruksi perempuan liyan menyebabkan pembaca sampai pada satu titik yakni mempertanyakan kembali kontruksi mengenai perempuan yang mungkin selama ini diterima sebagai hal yang lumrah dan alamiah.

Hal ini membuat analisis mengenai dekonstruksi perempuan liyan dalam ketiga cerita pendek karangan Intan Paramaditha menarik untuk diangkat. Dalam membongkar penggambaran perempuan tersebut, tulisan ini menggunakan teori abjek yang digagas oleh Julia Kristeva. 
Analisis mengenai perempuan sebagai abjek sudah banyak diangkat, Prabasmoro (2006) mengangkat persoalan abjek dan Monstrous Feminine terkait dengan Rahim, liur, tawa, dan pembalut. Penelitian yang diangkat Prabasmoro ini konteksnya sangat luas mengangkut film, iklan, dan berbagai mitos yang ada di masyarakat. Howe (2014) menganalisis representasi perempuan monster dan tubuh perempuan di karya sastra dengan genre roman di abad pertengahan. Karya sastra ini dianggap genrenya perempuan tapi menurut Howe sangat kental dengan nilai partriarki. Howe berargumen bahwa tubuh perempuan digunakan untuk mengukuhkan identitas kesatria tokoh laki-laki dan menunjukkan batasan femininitas dan maskulinitas. Penggambaran perempuan monster mengacaukan dan mengguncang normalitas sistem tersebut. Kedua penelitian tadi sudah sangat mendalam persoalan perempuan sebagai monster. Namun, Ketiga cerpen karya Intan Paramadita tersebut dibangun oleh kesadaran akan posisi abjek perempuan dengan beragam mitos yang dikonstruksikan pada perempuan oleh sistem partriarki. Dengan demikian penelitian ini akan menambah pemikiran kritis pada posisi marginal perempuan sekaligus upaya dekonstruksi terhadap posisi tersebut.

\section{METODOLOGI PENELITIAN}

Penelitian ini berupaya mengungkapkan dekonstruksi penggambaran perempuan abjek dalam tiga cerpen karya Intan paramaditha. Dalam analisis, artikel ini mengunakan metode deskriptif analisis yang berupaya menggambarkan fenomena yang ditemukan dengan mendetail. Penelitian ini juga menggunakan teori tentang Abjek yang digagas oleh Kristeva (1982).Abjek adalah istilah yang digunakan untuk menggambarkan sesuatu yang dianggap menjijikkan, menakutkan, inferior, tidak penting, buruk dan bahkan jahat. Kristeva (1982) mendefinsikan abjek sebagai

"something rejected from which one does not part, from which one does not protect oneself as from an object. Imaginary uncanniness and real threat, it beckons to us and ends up engulfing us" (p.4).

Abjek juga digunakan untuk melihat bagaimana sistem partriarki memandang perempuan. Glover dan Kaplan (2009) menjelaskan bahwa,

"abjection marks out a landscape of feeling by and about women that places them before, below and beyond culture-almost outside what can be represented within it. The evocation of abject feelings by women themselves hints at something stubbornly intractable in negative inflection of femininity" (p.32).

Berdasarkan pernyataan Glover dan Kaplan tersebut maka perempuan menjadi abjek karena pemaksaan terhadap identitas perempuan dengan femininitasnya oleh sistem patriarki.

\section{HASIL DAN PEMBAHASAN}

Perempuan menjadi dua "perempuan baikbaik" dan "perempuan jalang." (Creed, 2007). Perempuan yang tidak memenuhi standar femininitas akan dianggap jalang dan tidak bermoral. Standar femininitas ini merupakan konvensi yang ada di masyarakat, namun kurang lebih memuat konsep perempuan yang lembut, penurut, dan keibuan.

Cerita pendek Perempuan buta tanpa Ibu Jari, Vampir dan Darah merepresentasikan perempuan yang dianggap abjek karena tidak memenuhi standar femininitas yang ada dalam sistem patriarki tersebut. Ketiga cerpen ini berupaya mengaburkan batasan atara perempuan baik-baik dan perempuan jalang dengan cara mengetengahkan sudut pandang yang berbeda.

\section{Dekonstruksi Kakak dan Ibu Tiri dalam Cerita Perempuan Buta tanpa Ibu Jari}

Kakak dan Ibu tiri lekat dengan stigma negatif sebagai orang yang menjahati perempuan baik hati, lembut, dan cantik. Dikotomi perempuan baik-baik dan perempuan jalang terlihat sangat jelas dalam stigma tersebut. Namun, cerita pendek ini berupaya menyuguhkan hal yang berbeda.

Dalam cerita pendek "Perempuan Buta tanpa Ibu Jari” pembaca dibawa untuk mendengar suara perempuan yang dianggap abjek. Cerita pendek ini merupakan alusi dari kisah anak-anak Cinderella. Alih-alih menggunakan sudut pandang Cinderella, cerita ini mengambil sudut pandang kakak tirinya.

Melalui sudut pandang penceritaan dari sudut pandang kakak tiri Cinderella yang dalam cerita ini bernama Sinderalat, pembaca diajak untuk melihat kembali stereotipe perempuan yang dianggap jahat dan tidak memiliki karakteristik femininitas perempuan. Sosok kakak tiri yang abjek dipertegas dengan keadaan perempuan yang buta yang terkastrasi.

"Aku telah disembelih, ya bisa dikatakan
begitu. Dan aku pun telah menyembelih
diriku sendiri. Mataku ini buta karena
dipatuki burung" (Paramaditha, 2005, p.
27).

Perempuan yang buta dan telah dikastrasi 
menunjukkan perempuan yang seperti monster

Penggunaan kata sapaan "kamu" dalam cerita seolah ingin mendekatkan pencerita dengan pembaca. Cerita dibuat seakan pencerita sedang mengobrol dengan pembaca. Sapaan "nak" mengesankan ada perbedaan umur yang jauh antara pencerita dan pembaca. Pembaca seolah diposisikan sebagai seorang anak yang sering mendengar kisah Sideralat dan pencerita berupaya meluruskan mitos Sinderlarat yang sering didengarnya. Hal ini membuat pembaca diajak untuk melihat peristiwa kisah sinderalat dari sudut pandang kakak tiri, seperti yang terlihat di kutipan berikut.

\begin{abstract}
"Ayah memberi Larat gaun - gaun indah dan tiara mungil yang menghiasi rambutnya yang panjang bercahaya. Ia ingin anak perempuannya cantik seperti boneka hidup dengan bulu mata panjang berkedip genit, sedangkan kami diberinya pakaian bekas Larat. Masih bagus, tapi tetap saja bekas. Jika ayah berpergian, ia pulang dan membawakan banyak hadiah untuk Larat. Sementara aku dan adikku hanya mendapatkan sekotak manisan dan gaun murahan. Hati kami terbakar dengki. Apa boleh buat, kami dulu percaya bahwa pencapaian terbesar gadis remaja adalah gaun mewah melimpah" (Paramaditha, 2005, p.29).
\end{abstract}

Kutipan di atas memperlihatkan kisah Sinderlarat yang selama ini seakan merupakan korban dari ibu dan kakak tirinya menjadi dipertanyakan kembali. Sudut pandang di atas memang terkesan subjektif tapi juga memperlihatkan suara wanita selama ini dibungkam karena sudut penceritaan hanya menampilkan kisah Sinderalat.

Melalui suara kakak tiri tersebut, pembaca disuguhi kisah kakak tiri yang menderita karena perbedaan kasih sayang yang diberikan ayah tiri mereka. Ayahnya itu hanya memperhatikan dan memberikan yang terbaik untuk Sindelarat. Sementara itu, kakak tiri hanya mendapatkan baju bekas Sindelarat.

Suara kakak tiri juga menunjukkan bahwa ada tekanan dari lingkungan untuk menjadi perempuan cantik dengan gaun dan perhiasan yang mewah. Hal yang hanya dimiliki oleh Sinderalat. Kecantikan disandingkan dengan kebajikan yang merupakan hal yang harus dimiliki oleh seorang perempuan dan merepresentasikan kualitas moral dan spiritualnya (Davis, 1995). Pemikiran ini menempatkan perempuan cantik sebagai korban yang tidak berdosa yang dijahati oleh kakak tiri yang jahat dan buruk rupa. Meskipun memiliki ibu yang sangat cantik, kakak tiri mengikuti bentuk tubuh dan wajah ayahnya sehingga dia tidak mampu mengikuti standar kecantikan tradisional perempuan. Standar kecantikan memang berubah tiap jamannya namun yang tidak berubah adalah tekanan untuk menjadi cantik sesuai dengan standar tersebut.

Hal tersebut yang membuat perempuan berlomba-lomba untuk mencapainya meskipun dengan cara menyingkirkan perempuan lainnya.

Dekonstruksi terhadap sosok kakak tiri juga membuat dikotomi antara perempuan baik-baik dan perempuan jalang menjadi kabur. Kakak tiri menegaskan bahwa Sindelarat tidak naif bahkan kebaikan hatinya menjadi sebuah stategi dirinya untuk memenangkan hati ayahnya, ibu peri, dan juga pangeran. "Adik tiriku Larat memang pandai memasang muka manis" (Paramaditha, 2005, p. 31).

Melalui sudut pandang kakak tiri terlihat bahwa mepresentasikan diri sebagai perempuan baik-baik dihadapan ayahnya. Sinderalat hanya meminta sekuntum bunga saat kakak tiri meminta hadiah mewah. Namun, hal itu dapat terjadi karena memang Sindelarat telah memiliki semuanya. Ayahnya akan membelikan segala kemewahan itu tanpa diminta. Sementara itu, kakak tirinya tidak mendapatkan kemewahan yang sama.

Upaya Sinderalat untuk dapat hadir di pesta Dansa menurut kakak tiri sebagai pertanda bahwa Sinderalat sebenarnya materialistik.

Perhatikan betapa ia ingin menampilkan citra gadis baik-baik yang tidak materialistis. Puh! Sangat tidak realistis. Kalau tak perduli kekayaan, mengapa dia bersikeras pergi ke pesta untuk bertemu Gusti Pangeran mahakaya?" (Paramaditha, 2005, p.31).

Kakak dan ibu tiri sudah mengakui mereka materialistis karena hal itu penting dalam bertahan hidup. Pernikahan dengan ayah Sindelarat juga salah satu upaya ibu tiri untuk bertahan hidup dan mampu membesarkan anaknya. Namun, berdasarkan suara kakak Tiri, Sinderlarat tidak jauh beda dengan dirinya. Sikap masih dan baik hati bukan diri Sinderalat karena merupakan bentuk performatif yang dilakukan oleh Sinderalat demi mendapatkan kasih sayang ayahnya dan juga mendapatkan pangeran. Pandangan mengenai kedatangan Sidelarat yang terkesan alamiah dalam kisah Cinderella dibongkar sebagai strategi Sindelarat untuk mendapatkan kekayaan.

Dengan demikian, penceritaan dari sudut pandang kakak tiri ini mendekontruksi dikotomi perempuan baik-baik dan perempuan jalang. Perempuan baik-baik hanya merupakan performatif 
yang sebenarnya tidak berbeda dari perempuan yang dilabeli sebagai jalang.

Bukan hanya sosok kakak tiri dan Sinderalat yang berupaya didekonstruksi tapi juga sosok ibu tiri. Alih-alih menampilkan ibu tiri yang kejam, cerita pendek ini menggambarkan seorang ibu yang berusaha bernegosiasi dengan opresi terhadap perempuan. Kecantikan ideal menurut Calogero, Borough, dan Thomson (2007) berkaitan dengan kesuburan, kekuatan ekonomi dan politik, dan identitas gender. Hal ini membuat perempuan yang tidak cantik terpinggirkan khususnya dalam persaingan memeroleh suami.

Tindakan ibu tiri mengurung Sinderalat karena kekhawatirannya bahwa Sideralat akan menikah lebih dulu dari kakak-kakaknya. Sindelarat sangat cantik jadi tidak akan sulit baginya memeroleh suami.

Dan betapa was-wasnya kami kala
mengetahui para laki-laki mengantre di
depan pintu hanya untuk melamar Larat!
Ibuku mencoba bernegoisasi, "Larat masih
muda. Bagaimana kalau Kakak-kakaknya
menikah lebih dulu?" Tapi rupanya tak ada
yang beminat pada kami. Ibuku marah
sekaligus takut kami menjadi perawan tua
sehingga ia menyuruh Larat bersembunyi di
loteng jika tamu datang. Begitulah, dalam
kompetisi para perempuan harus
menyingkirkan lawan dengan penuh
kebencian" (Paramaditha, 2005, p.12).

Kutipan di atas memperlihatkan gambaran dari opresi terhadap perempuan untuk menjadi cantik. Kecantikan menjadi sebuah cara perempuan untuk memeroleh kekuatan ekonomi dan juga masa depan. Pernikahan merupakan satu cara buat memeroleh kenyamanan, keamanan, dan kepastian ekonomi. Hal ini membuat pernikahan menjadi satu hal yang penting untuk perempuan.

Ibu tiri lahir dari keluarga miskin, hidupnya terangkat menjadi lebih baik saat dia menikahi seorang bupati meskipun dengan mendapat cap sebagai perebut suami orang.

Dengan kata lain cerita pendek ini menunjukkan opresi terhadap perempuan dan upaya perempuan untuk bernegosiasi dengan opresi tersebut. Perempuan juga dikondisikan untuk berkompetisi karena menikah adalah satu-satunya jalan untuk menjamin hidup mereka di dunia yang makin mendewakan materi. Ibu tiri juga berfikir demikian inilah yang menyebabkan aksinya mengurung Larat. Dia beranggapan Larat masih muda dan sangat cantik, maka tidak akan sulit baginya untuk menikah.
Penggambaran ini memperlihatkan sebuah sistem yang dipaksakan terhadap perempuan. Hanya perempuan yang cantik yang dihargai sedangkan yang hitam dan jelek tidak mendapat tempat di masyarakat. Dari cerita ini pembaca bisa melihat sosok yang dianggap buruk dan abjek, mungkin juga ingin menyuarakan alasanya melakukan tindakan yang dianggap masyarakat sebagai hal yang buruk. Pembaca juga diajak untuk bersimpati kepada kakak tiri ini karena dia hanya melakukan apa yang diketahuinya sebagai perempuan. Bahkan dia harus merelakan kakinya dipotong demi mendapatkan masa depan yang baik.

\section{Dekonstruksi Perempuan Perusak Rumah Tangga dalam Cerita "Vampir"}

Cerita pendek "vampir" menggambarkan kisah hidup seorang sekretaris dan sesosok makhluk tidak bernama. Kisah ini mengangkat stereotipe yang dilekatkan dengan profesi itu dan berupaya mendekonstruksi penggambaran negatif tersebut. Melalui penggunaan dua sudut pandang berbeda (multiple point of view) dengan narasi akuan, penceritaan mampu mengungkap suara tokoh bukan hanya dari penampakan luar namun juga suara batin tokoh.

Penggunaan sudut padang tersebut juga membuat cerita pendek ini mampu menghadirkan dikotomi perempuan baik-baik dan perempuan jalang. Perempuan baik-baik direpresentasikan oleh sosok sekretaris yang selalu berupaya menjaga integritasnya dan professionalitasnya. Tokoh kedua adalah sosok tak bernama yang mereprentasikan judul cerita pendek tersebut "vampir."

Di satu sisi pembaca diajak untuk merasakan pergolakan batin tokoh sekretaris dan keputusankeputusan yang diambilnya. Di sisi lain, pembaca seakan dibawa ke alam lain, seperti alam bawah sadar yang gelap, tidak diinginkan, dan disingkirkan (abjek). Menurut Kristeva (1982) abjek itu menyimpang dan tidak taat aturan dan mengganggu diri. Seseorang dapat memeroleh subjektivitasnya dengan memisahkan diri dari abjek sama seperti seorang anak yang masuk dalam fase "semiotik" dengan mengabjek tubuh ibunya dan tunduk pada kekuasaan ayah. (prabasmoro, 2006). Lebih lanjut Prabasmoro mengungkapkan bahwa tubuh ibu adalah "universe without shame" yakni tidak adanya batasan antara tubuh kotor dan bersih. Hal ini harus ditinggalkan dan mengikuti hukum ayah agar menjadi subjek.

Penggambaran dikotomi antara tubuh maternal dan hukum ayah terlihat melalui tokoh sekretaris dan vampir. Sosok sekretaris merepresentasikan perempuan baik-baik yang selalu rajin, teratur dan taat terhadap norma-norma 
yang berlaku. Sebagai seorang sekretaris, tokoh utama menyadari bahwa dirinya dekat dengan perselikuhan, apalagi sosok bos yang muda dan tampan. Tokoh utama berusaha menepis segala keinginan negatifnya. Dia berusaha professional dan tidak ingin berbuat tidak senonoh dengan bosnya. Fokus utamanya hanyalah bekerja dengan baik.

Sementara itu, sosok vampir hidup di tempat yang "sempit, basah dan gelap dan tidak diinginkan" (Paramaditha, 2005, p.19) tapi dia berasal dari tempat yang sama dengan tokoh perempuan. "Ah! Ah! Aku saudara yang berbagi hangat denganmu ditempat merah sempit itu" (Paramaditha, 2005, p. 23).

Sosok vampir yang mengaku berasal dari tempat yang sama dengan sang sekretaris seolah menunjukkan bahwa pada dasarnya sosok vampir ini adalah bagian dari diri sekretaris sendiri yang merupakan bagian dari tubuh maternal. Tubuh ini tidak membedakan mana yang kotor dan bersih merupakan dunia yang tidak mengenal rasa malu (universe without shame).

Sosok vampir ini adalah sosok harus disingkirkan oleh tokoh sekretaris agar dia dapat menjadi subjek yang memenuhi hukum ayah. Namun, sosok abjek itu terus membayangi hidup tokoh utama dan membisikinya untuk memuaskan hasratnya. "Ayo marah! Tidakkah kau impikan semua kebinatangan di balik rokmu yang beradab?" (Paramaditha, 2015, p.23). Tokoh sekretaris yang berusaha menerapkan profesionalisme tetapi di akhir cerita dia tidak bisa menahan keinginannya untuk merasakan kenikmatan bersama bosnya yang tampan tersebut. Pada akhir cerita inilah suara tokoh utama bergabung dengan sosok vampir yang selama ini membayanginya

Aku gemetar. Tiba-tiba kusadari ketakutan
terbesarku terjadi. Aku pernah
membayangkannya, dan karena aku sangat
professional, aku tahu aku harus
mendorongnya dengan tegas, mengusirnya
bila perlu.Tapi aku merasa ia semakin
mendekatkan tubuhnya padaku. Aku bisa
mencium minyak wangi bercampur aroma
rokok yang menempel di rambutnya yang
tercukur rapi. Aku seperti .... (Paramaditha,
2005, p. 26)

Suara tokoh utama kemudian bersatu dengan makhluk abjek yang ditakutinya. Penyerahan dirinya menjadi dia makhluk yang abjek dengan cap perempuan nakal atau perusak rumah tangga orang karena berhubungan dengan orang yang telah beristri.
Bersatunya sosok sekretaris dan sosok abjek dapat dimaknai beberapa hal. Pertama, Sosok abjek adalah sosok yang menympang yang ingin dibuang dan disingkirkan karena tidak sesuai dengan diri yang bersih. Namun, Abjek seperti dua sisi mata uang di satu sisi disingkirkan, di sisi lain memberikan kenikmatan (Prabasmoro, 2006). Bersatunya kembali antara tokoh sekretaris dengan vampir mengaburkan batasan dikotomi perempuan baik-baik dan perempuan jalang sekaligus mengaburkan batasan antara diri dengan hasrat. Batasan yang digariskan oleh hukum ayah terlanggar dan perempuan kembali ke tubuh maternal.

Kedua, penggambaran ini mendekonstruksi stigma perempuan perebut suami karena bukan tokoh sekretaris yang sengaja menggoda bosnya. Tapi bosnya yang menginisiasi terjadinya perselingkuhan itu. Tokoh sekretaris telah berusaha untuk menjaga integritasnya. Hal ini merupakan upaya untuk mendekonstruksi stigma negatif bahwa perempuanlah yang salah ketika terjadi perselingkuhan. Stigma ini sering menempatkan perempuan dalam posisi yang dipersalahkan sementara laki-laki yang melakukan perselingkuhan tidak mendapatkan stigma yang sama.

\section{Dekonstruksi perempuan monster dalam Cerita Darah}

Cerita pendek dengan judul "Darah" berupaya mengkonfrontasi konstruksi perempuan monster. Sundelbolong, pocong, dan suster ngesot adalah beberapa contoh pengabjekan perempuan dan memosisikannya sebagai sosok monster yang menakutkan dan harus dibuat untuk tatanan hidup yang lebih baik.

Upaya untuk menekonstruksi sosok monster perempuan dihadirkan melalui kisah seorang copy writer yang berupaya membuat iklan tentang pembalut. Dalam proses pembuatan iklan tersebut tokoh perempuan selalu mengaitkannya dengan "monster, lembab, banjir, bau" segala hal yang tidak menyenangkan lainnya. Hal ini membuatnya kesulitan untuk membuat iklan yang sesuai dengan keinginan klien. Dia bahkan bermimpi buruk berlari dari terjangan gulungan air dan tenggelam saat rapat pembuatan iklan.

Ketakutan dan mimpi buruk yang dialami oleh tokoh perempuan tersebut ditengarai merupakan trauma yang muncul kembali dipicu oleh keharusannya menggali kembali ingatan mengenai hal yang dihindari dan dibuang.

Jangan-jangan sekarang. Itu yang ada dibenakku saat dipaksa menyambutnya di bulan puasa. Aku masih kelas lima. Sendirian. Ibuku meninggal setahun 
sebelumnya, saat melahirkan (Paramaditha, 2005, p. 115).

Alih-alih mampu memikirkan ide untuk iklan yang dibuatnya. Tokoh perempuan teringat pertema kali mendapatkan menstruasi saat dia masih kelas lima SD setahun setelah ibunya meninggal. Meskipun ibunya telah mengajarinya mengenai apa yang harus dilakukan saat mengalami menstruasi, ayah tokoh perempuan meminta guru mengaji mengajari anaknya mengenai menstruasi.

Berbagai aturan, stigma, doktrin, dan mitos tertanam di benak tokoh perempuan. Dia mengaitkan menstruasi dengan "Darah. Dosa. Tubuh kotor. Dosa kotor. Dosa tubuh" (Paramaditha, 2005, p. 119). Segala hal yang abjek dan harus dihindari dan dibuang untuk meraih subjek. Tubuh perempuan memang dianggap abjek karena bukan merupakan tubuh yang solid sebagaimana tubuh laki-alaki. Creed (2007) mengutip dari Kristeva menjelaskan bahwa fungsi maternal (reproduksi) perempuan membuat tubuh perempuan menjadi abjek. Tubuh perempuan banyak keluar cairan dan dapat membelah diri membuatnya dianggap sebagai sosok abjek yang menakutkan. Penggambaran ini mengungkap dikotomi yang bersih dan yang kotor, pantas, dan tidak pantas. Konstruksi ini yang kemudian terinteranalisasi dalam pemikiran tokoh perempuan sehingga sulit mengaitkan hal-hal yang baik dengan menstruasi.

Mitos mengenai monster perempuan yang mengejar darah menstruasi juga terus terngiang di benak tokoh perempuan. Sosok abjek penghisap darah ini diceritakan sebagai perempuan berambut panjang dan berwajah pucah dengan bibirnya yang merah penuh darah. (Paramaditha, 2005). Hantu perempuan itu akan memburu darah menstruasi di pembalut yang tidak dibersihkan saat dibuang. Tokoh perempuan selalu diingatkan ustazahnya bahwa dia harus berhati-hati membuang pembalutnya. "Darah adalah ketakutan. Kegilaan. Perempuan yang sedang menstruasi bisa menebar terror" (Paramaditha, 2005, p.121). Darah menjadi hal yang dianggap kotor dan menakutkan.

Darah juga mengingatkan tokoh perempuan pada kematian ibunya saat melahirkan adiknya. Kematian ibunya itu sangat traumatis bagi tokoh utama. Ingatan kematian ibunya hadir antara mimpi dan kesadaran. Tokoh perempuan terbangun dari tidur karena ingin ke kamar mandi, tapi bukan dia bukan berada di kamar tidurnya tapi di koridor rumah sakit. Dengan pengertian lain, tokoh perempuan ditarik ke memori masa lalunya saat menyaksikan kematian ibunya. Ingatan yang lekat dalam benaknya adalah darah yang beragam rupa.

\begin{abstract}
Aku tak mampu melihat apa yang ada di antara kaki-kaki itu. Merah. Biru. Cat air yang kental menggumpal, membaur tak terpisahkan. Darah beragam rupa, mirip teh pekat, sirup stoberi, jeli. Ibu berteriak, Suaranya sepedih serigala kesepian (Paramaditha, 2005, p. 125).
\end{abstract}

Ingatan di atas sangat dipengaruhi oleh sudut padang anak-anak. Tokoh perempuan yang saat itu kelas empat SD mengaitkan darah dengan cat air, teh pekat, sirup stroberi, jeli. Hal-hal yang dikenalnya. Namun tepat setelah suara jeritan ibu dan menjelang kematian ibunya, tokoh perempuan mengganti posisi sebagai anak yang melihat ibunya ke posisi penonton yang melihat seorang anak yang menyaksikan ibunya meninggal. "Anak itu terpaku melihat darah di antara kedua kaki ibunya" (Paramaditha, 2005, p. 125).

Pemindahan mata yang pengamat menunjukkan rasa trauma tokoh utama mengingat kematian ibunya. Tokoh utama menggunakan tubuh lain untuk menjadi mediator ingatannya. Meskipun demikian, anak tersebut dapat disimpulkan adalah dirinya sendiri.

Meskipun berkaitan dengan trauma, menstruasi dalam cerita pendek ini dikaitkan dengan resistensi tokoh utama. Dia menggunakan darah menstruasi sebagai pembalasan dendam terhadap kekasihnya yang menuduhnya bukan perawan setelah mereka melakukan hubungan badan. Dia mengajak kekasihnya itu berhubungan kembali saat sedang haid dan menunjukkan darah yang menurutnya dicari oleh kekasihnya.

Dengan demikian meskipun darah menstruasi itu abjek yang harus disingkirkan untuk keberlangsungan hidup dan menyebabkan trauma, tokoh utama masih meraihnya sebagai bagian kenikmatan yang menyimpang.

Ketidakmampuan tokoh perempuan dalam menemukan ide untuk iklan pembalit membuatnya memilih mengundurkan diri dari kantornya dan terbebas dari kungkungan sistem kapitalis yang mengekang kinerja dan kretivitasnya. Pada akhir cerita, Tokoh perempuan dipertemukan dengan sosok monster perempuan pemburu darah.

Pertemuan itu menegaskan dekonstruksi monster perempuan yang diangkat dalam cerita pendek ini. Tokoh perempuan menyadari ada sudut pandang lain dari kisah monster dan darah.

Kau perempuan yang diceritakan guru
mengajiku.

Kau menoleh. Seharusnya aku takut, tapi aku begitu ingin melihatmu. Wajahmu seperti 
kertas buku tua yang kumal dan pucat. Lingkaran hitam membingkai matamu yang menonjol seperti kelereng, seolah dibubuhi abu, namun anehnya, bibirmu merah basah, segar. Indah.

\section{Mengapa kau begitu menyukai darah?}

Suaramu serak dan pelan, begitu jauh, begitu purba, namun bisa kudengar kau berbisik,

\section{Karena darah adalah hidup.}

Sesederhana itu. (Paramaditha, 2005, p.128)

Kutipan di atas mendekonstruksikan makna darah yang sering dianggap kotor dan dosa. Begitupun perempuan yang sedang menstruasi diidentikkan dengan kotor dan membawa teror. Dalam cerita ini Darah dan sosok hantu penghisap darah didekontruksi menjadi bukan hal yang menakutkan. Jika dilihat dari dekat sosok hantu penghisap darah ini tidaklah menakutkan. Bahkan bibirnya terlihat segar dan indah. Darah itu sendiri tidaklah kotor tapi merupakan sumber kehidupan.

Cerita pendek berjudul "Darah" ini mengkonfrontasi yang abjek namun kemudian menerima abjek tersebut sebagai hal yang natural dan normal. Dengan pengertian lain, cerita pendek ini merayakan tubuh maternal dengan meninggalkan hukum ayah.

\section{KESIMPULAN}

Perempuan yang dimarginalkan sering tidak mempunyai kesempatan untuk menyuarakan dirinya. Tiga cerita pendek karya Intan Paramaditha yaitu "Perempuan Buta tanpa Ibu Jari", "Vampir", dan "Darah" memberikan penggambaran suara dari perempuan marginal yang dianggap abjek. Abjek karena mereka dianggap menjijikan, menakutkan dan membuat teror. Tapi mereka juga adalah korban dari sistem patriarki yang menempatkan mereka sebagai sosok yang buruk karena tidak sesuai dengan feminitas yang harusnya dimiliki oleh perempuan. Sistem yang sebenarnya dipaksakan dan banyak ambiguitas dalam berbagai seginya. Ketiga cerita pendek tersebut membongkar konstruksi abjek tersebut dengan mengaburkan batasan antara yang diri yang bersih dan kotor, monster dan manusia, serta perempuan baik-baik dan perempuan jalang. Pengaburan batasan itu mengoyang struktur kekuasaan patriarki dan merayakan tubuh maternal.

\section{REFERENSI}

Becker, M.-L. (2007). Julia Kristeva and literary theory. New York: Palgrave Macmillan

Calogero, R. M., Boroughs, M. dan Thompson, J.K. (2007). The impact of western beauty ideals in the lives of women: A sociocultural perspective in Swami, V. et.al. (eds) (2007) The body beautiful. New York: Palgrave Macmillan

Creed, B. (2007). The monstrous feminine: Film, feminism, psychoanalysis. London and NewYork: Routledge

Davis, K. (1995). Beauty and the female body in "Reshaping the female body: The dilemma of cosmetic surgery", Routlegde, p. 39-67

Glover, D. dan Kaplan (2009). Genders. London and New York: Routledge

Howe, J. L. (2014). Monstrous femininity and the female body in medieval chivalric romance. Dissertation. Tuft University

Kristeva, J. (1982). Power of horror: An essay on abjection (Leon S Roudiez, Trans). New York: Columbia University Press

Paramaditha, I. (2005). Sihir perempuan. Depok: Katakita

Prabasmoro, A. P. (2006). Kajian budaya feminis: Tubuh, sastra, dan budaya pop. Jakarta: Jalasutra

Tong, R. P. (1998). Feminist thought: Pengantar paling komprehensif kepada arus utama pemikiran feminis (Aquarini Priyatna, trans) Yogyakarta: Jalasutra 